\title{
Numerical Simulation and Investigation of an Atrium Fire Experiment
}

\author{
Ibrahim H. Hassanien ${ }^{1}$, Sameh Shabaan ${ }^{2}$, and Essam E. Khalil ${ }^{3}$
}

\begin{abstract}
Atriums are large open spaces like airports, stadiums, train stations, and malls require performance-based design of smoke management systems to address life safety concerns in the building codes. The purpose of smoke management is to secure a tenable environment for the evacuation of the occupants. Fire Dynamic Simulator (FDS) is a Computational Fluid Dynamics (CFD) model developed by National Institute of Standards \& Technology (NIST) especially for fire applications. The validation of fire experiment in a $20 \mathrm{~m}$ cubic Atrium using FDS has been conducted to address the differences between numerical models and experiment measurements. This paper discusses and explains the reasons behind these differences according to American society for Heating, Refrigeration and Airconditioning (ASHRAE) Guides.
\end{abstract}

Keywords - CFD, FDS, Smoke, Validation.

\section{INTRODUCTION}

MOKE is recognized the major killer in buildings fire. S Smoke control engineering has been developed as a research topic since the Ring Theater fire in Vienna at 1881, which killed 449 people [1]. Since then, many design techniques have been developed to ensure a tenable evacuation during fire. An atrium could be defined as a space with at least two stories height, which is commonly used now days by architects in several applications. Smoke hazard includes reduced oxygen levels; ending by people suffocation, very high temperature and reduced visibility; which will obstacle people during evacuation. Smoke control systems' major objective is to control the spread of smoke through the building and secure the minimum make-up fresh air required for the evacuated people. Protecting the egress paths and ensuring that the smoke layer height is not lower than the emergency exit signs level are major objectives too, along with securing areas for refuges and facilitate firefighter's access.

Ibrahim H. Hassanien ${ }^{1}$ is a mechanical engineer and master's degree student at Arab Academy for Science, Technology, and Maritime Transport, Cairo, Egypt. (corresponding author's phone: +201003485521; e-mail: ibrahimhh2@gmail.com).

Sameh Shaaban ${ }^{2}$ is an Associate Professor in Arab Academy for Science, Technology, and Maritime Transport. (e-mail: sameh.shaaban@aast.edu).

Essam E. Khalil ${ }^{3}$ is a Professor of mechanical engineering in Cairo University, Cairo, Egypt. (e-mail: khalile1@asme.org).
The current trend in smoke control engineering is to go for performance-based design using CFD software's like FDS. The models accuracy shall be validated against reliable and comprehensive full scale tests to assure that the simulation outcomes are within accepted limits. This paper validates a 20 $\mathrm{m}^{3}$ atrium fire experiment and discusses and explains the results.

\section{MODEL DESCRIPTION}

The Murica Atrium Fire Test [2] which has been carried out in the Atrium of the Centro Technologico del Metal, in Murcia, Spain is considered as the validation case in this research. This full-scale facility consists of a prismatic structure of $19.5 \mathrm{~m} \times 19.5 \mathrm{~m} \times 17.5 \mathrm{~m}$ and a pyramidal roof raised $2.5 \mathrm{~m}$ at the center. The walls and the roof are made of $6 \mathrm{~mm}$ thick steel and the floor is made of concrete. There are four exhaust outlets installed on the roof, each with a diameter of $0.56 \mathrm{~m}$ and eight grilled vents arranged at the lower parts of the walls. Each vent has dimensions of $4.88 \mathrm{~m} \times 2.5 \mathrm{~m}$ as shown in Fig. 2. The test burning fuel was heptane contained in circular steel pans placed in the center of the atrium floor. The pool fire diameter was $1.17 \mathrm{~m}$ and the heat release rate (HRR) was 2.3 MW. The heat release rate with time is shown in Fig. 1 below. Ten Temperature sensors were installed at different locations inside the testing facility in order to study the thermal effect of the fire. The locations of the sensors were as follows;

- Three sensors (T-01, T-04, \& T-07) were installed at the center of wall-A, only $0.3 \mathrm{~m}$ away from the wall, with heights of $15.15,10.15, \& 5.15 \mathrm{~m}$ respectively.

- Three sensors (T-13, T-16, \& T-19) were installed at the center of wall-C, only $0.3 \mathrm{~m}$ away from the wall, with heights of $15.15,10.15, \& 5.15 \mathrm{~m}$ respectively.

- Three sensors (T-28, T-31, \& T-24) were installed at the center of the atrium, right above the fire, with heights of $12.55,8.55, \& 4.55 \mathrm{~m}$ respectively.

- One sensor (T-60) was installed at the exhaust outlet close to wall-C. 


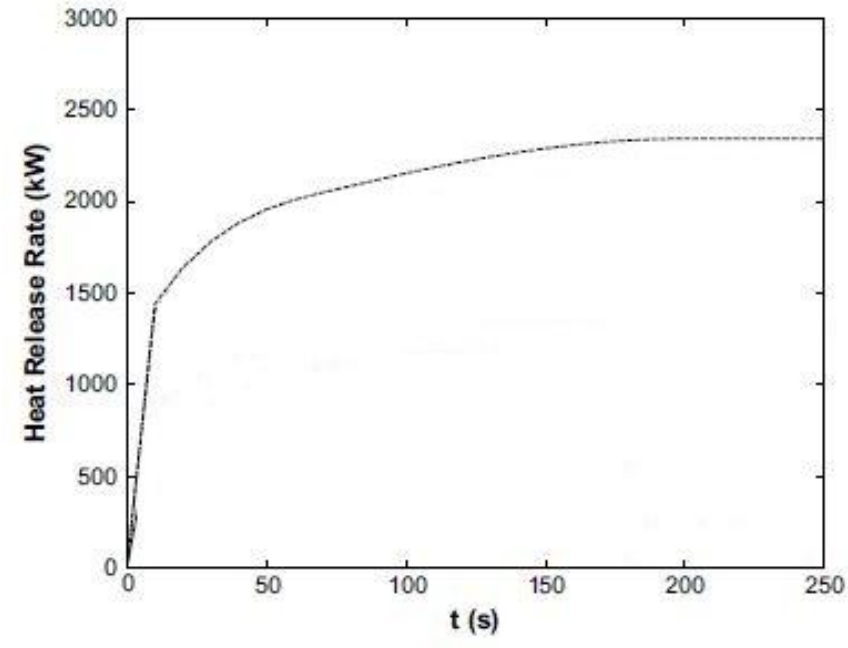

Fig. 1 Murica fire test heat release rate with time [3]

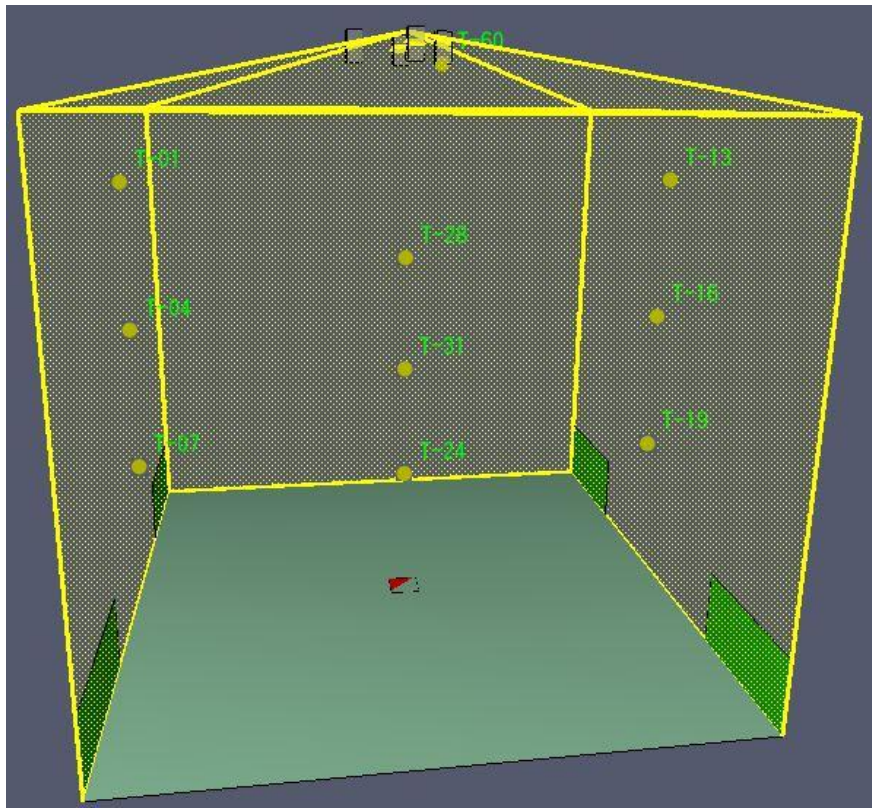

Fig. 2 Temperature sensors locations inside the atrium model

\section{INPUT PARAMETERS}

A summary of laboratory and ambient conditions during the fire test is indicated in Table I below.

TABLE I

SUMMARY OF LABORATORY AND AMBIENT CONDITIONS DURING THE FIRE

\begin{tabular}{|l|c|}
\multicolumn{2}{|c|}{ TEST. } \\
\hline Pool diameter $(\mathrm{m})$ & 1.17 \\
\hline Volume of heptane $(\mathrm{l})$ & 100 \\
\hline Burning time $(\mathrm{s})$ & 1094 \\
\hline Ambient temperature $\left({ }^{\circ} \mathrm{c}\right)$ & 16 \\
\hline Ambient pressure $(\mathrm{mbar})$ & 997 \\
\hline Ambient humidity $(\%)$ & 49 \\
\hline Wind speed $(\mathrm{m} / \mathrm{s})$ & 0.75 \\
\hline Average HRR $(\mathrm{MW})$ & 2.34 \\
\hline
\end{tabular}

The venting conditions during this fire test were as the following;
- The four $4.88 \mathrm{~m} \times 2.5 \mathrm{~m}$ vents are $100 \%$ open.

- The four $0.56 \mathrm{~m}$ diameter exhaust outlets at the roof are completely open (natural ventilation).

\section{GRID SENSITIVITY ANALYSIS}

The major effect on CFD results is the grid/mesh size [4]. Hence, a grid sensitivity analysis has been carried out to identify the grid/mesh size. The fire plume simulation resolution $\left(\mathrm{R}^{*}\right)$ is a dimensionless parameter defined as the number of grid cells length $(\partial x)$ that span the characteristic diameter of the fire, as in equation (1) below [8]. The characteristics of fire diameter $\left(D^{*}\right)$ is a useful length scale that incorporates the heat release rate of the fire, as in eq. (2) below [5]. Studies suggested that the resolution shall be $1 / 5$ to $1 / 10[6]$.

$$
\begin{aligned}
D^{*} & =\left(\frac{\dot{Q}}{\rho_{\infty} c_{p} T_{\infty} \sqrt{g}}\right)^{2 / 5} \\
R^{*} & =\frac{\max (\delta x, \delta y, \delta z)}{D^{*}}
\end{aligned}
$$

\footnotetext{
Where;

$\mathrm{D}^{*}$ : Characteristic fire diameter, $\mathrm{m}$;

$\dot{\mathrm{Q}}$ : Total HRR, W;

$\rho \infty$ : Density at ambient temperature, $\mathrm{Kg} / \mathrm{m}^{3}$

$C P \quad:$ Specific heat of gas, $\mathrm{J} / \mathrm{Kg} . \mathrm{K}$;

$T \infty$ : Ambient temperature, $\mathrm{K}$;

$g:$ Acceleration of gravity, $\mathrm{m} / \mathrm{s}^{2}$
}

TABLE II

Number of CELLS NEEDED IN EACH DiRECTION FOR DIFFERENT GRID

\begin{tabular}{|c|c|}
\hline \multicolumn{2}{|c|}{ RESOLUTION. } \\
\begin{tabular}{|c|c|}
\hline HRR (MW) & 2.34 \\
\hline Cells number for $\mathrm{R}^{*}=1 / 5$ & 74 \\
\hline Cells number for $\mathrm{R}^{*}=1 / 10$ & 148 \\
\hline
\end{tabular}
\end{tabular}

In the grid sensitivity study; the grid size is systematically increased until the difference between the results is minor when compared to computational time. Six grids have been studied, 40,60, 90, 120, 150, and 180 cells per side of the cubic atrium. To make the sensitivity analysis simple, the following has been considered;

- Only four temperature sensors have been considered, with $5,9,13$, and 17 meters height at the center of the atrium right above the fire.

- The heat release rate is set constant and 100 seconds are simulated for each grid size.

- The temperatures have been averaged for the last 80 seconds at each height.

The number of cells for each trial is as in Table III below. 
TABLE III

TEMPERATURE PREDICTIONS AT EACH NUMBER OF CELLS

\begin{tabular}{|c|c|}
\hline $\begin{array}{l}\text { Number of cells at each } \\
\text { direction }\end{array}$ & $\begin{array}{l}\text { Total number of cells in } \\
\text { the model }\end{array}$ \\
\hline 40 & 64,000 \\
\hline 60 & 216,000 \\
\hline 90 & 729,000 \\
\hline 120 & $1,728,000$ \\
\hline 150 & $3,375,000$ \\
\hline 180 & $5,832,000$ \\
\hline
\end{tabular}

The output of the grid sensitivity study is illustrated in Table IV below.

TABLE IV

TEMPERATURE PREDICTIONS AT EACH NUMBER OF CELLS

\begin{tabular}{|c|c|c|c|c|c|c|}
\hline \multirow{2}{*}{$\begin{array}{c}\text { Height } \\
(\mathrm{m})\end{array}$} & \multicolumn{6}{|c|}{ Temperature predictions $\left({ }^{\circ} \mathrm{c}\right)$ at each grid size } \\
\cline { 2 - 7 } & $40^{3}$ & $60^{3}$ & $90^{3}$ & $120^{3}$ & $150^{3}$ & $180^{3}$ \\
\hline 17 & 76.7 & 74.1 & 104.0 & 75.8 & 54.5 & 53.6 \\
\hline 13 & 92.1 & 96.8 & 147.9 & 117.3 & 72.8 & 70.4 \\
\hline 9 & 120.3 & 143.6 & 225.3 & 234.5 & 135.2 & 131.3 \\
\hline 5 & 201.0 & 256.6 & 411.0 & 521.8 & 451.0 & 462.3 \\
\hline
\end{tabular}

The relative error from each grid to the finest grid is illustrated Table V below.

TABLE V

TEMPERATURES RELATIVE ERRORS TO THE FINEST GRID

\begin{tabular}{|c|c|c|c|c|c|}
\hline \multirow{2}{*}{$\begin{array}{c}\text { Height } \\
(\mathrm{m})\end{array}$} & $40^{3}$ & $60^{3}$ & $90^{3}$ & $120^{3}$ & $150^{3}$ \\
\cline { 2 - 6 } & 43 & 38 & 94 & 41 & 2 \\
\hline 17 & 31 & 37 & 110 & 67 & 3 \\
\hline 13 & 8 & 9 & 72 & 79 & 3 \\
\hline 9 & 57 & 44 & 11 & 13 & 2 \\
\hline 5 & & & & \\
\hline
\end{tabular}

Comparison of the results for the different grids showed that the relative error with respect to the finest grid is high for the $40,60,90,120$ cells and very low in the 150 cells (below 5\%). Hence, the 150 cells per side were chosen to be implemented in the present validation case.

\section{V.SIMULATION OUTCOMES}

The simulation of the fire experiment has been carried out

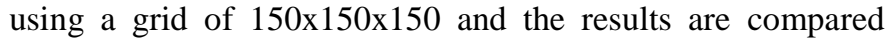
with the experimental measurements and previous simulation [3]. Each of the below figures illustrates the present temperature predictions by the present FDS model along with the experimental measurements and previous FDS predictions.

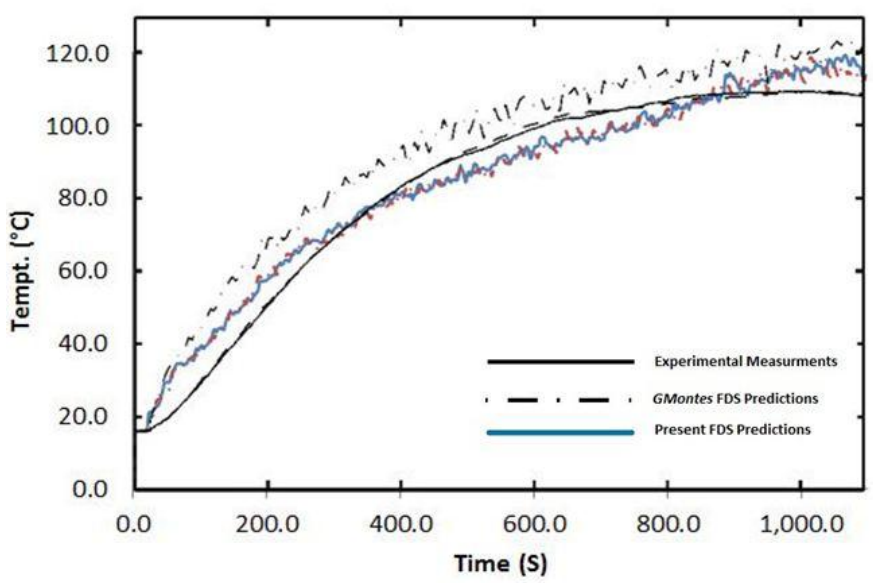

Fig. 3 Present CFD Predictions Vs. Previous Experimental Measurements [3], for Tempt. Sensor (T-01\&13)

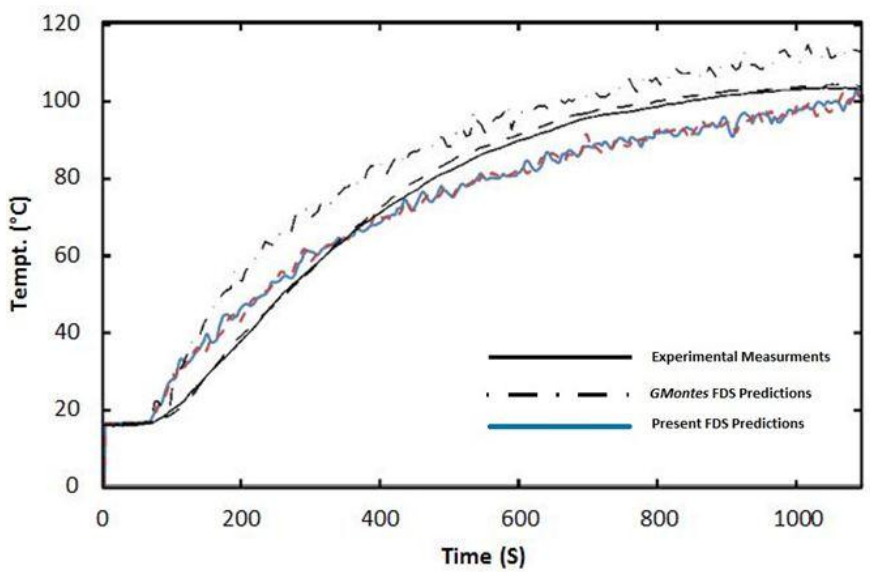

Fig. 4 Present CFD Predictions Vs. Previous Experimental Measurements [3], for Tempt. Sensor (T-04\&16)

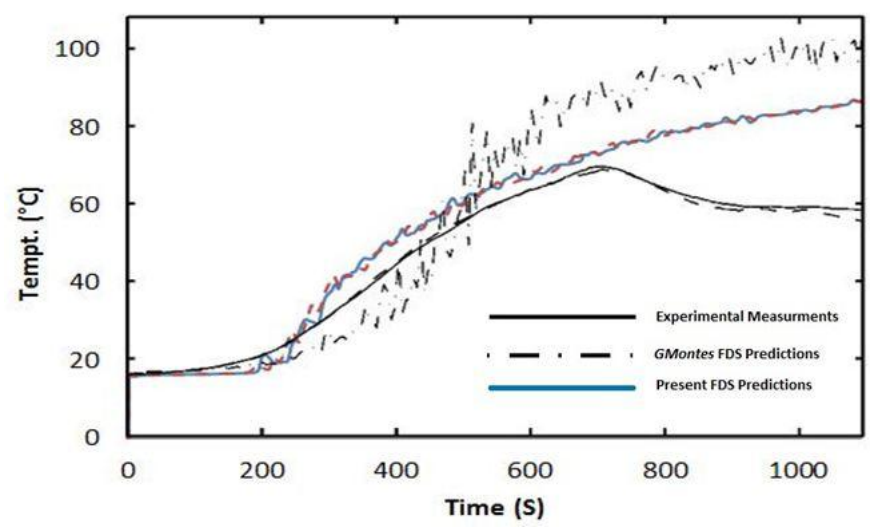

Fig. 5 Present CFD Predictions Vs. Previous Experimental Measurements [3], for Tempt. Sensor (T-07\&19) 


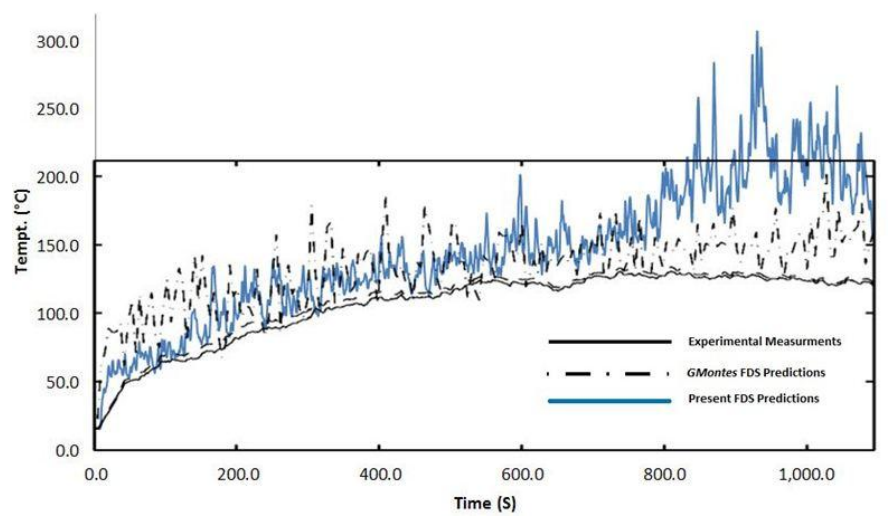

Fig. 6 Present CFD Predictions Vs. Previous Experimental Measurements [3], for Tempt. Sensor (T-28)

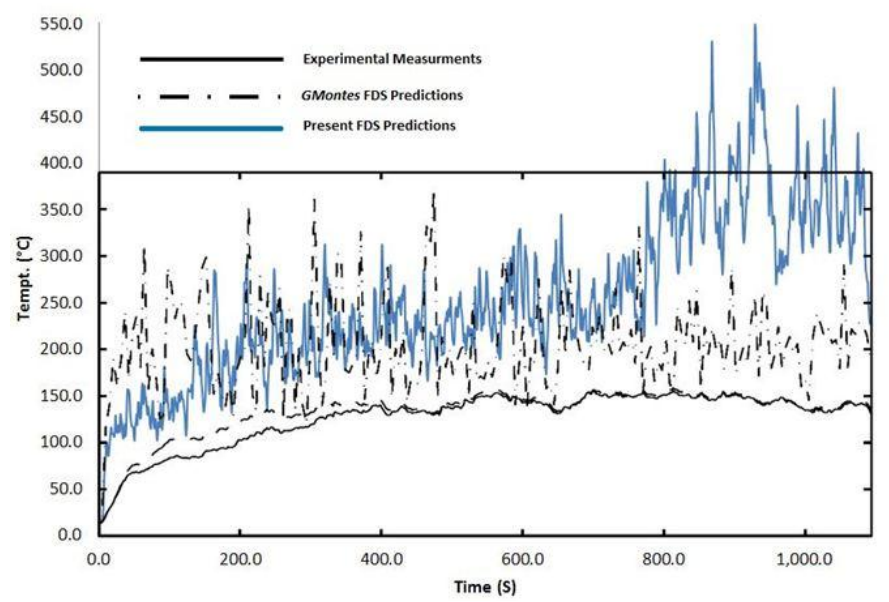

Fig. 7 Present CFD Predictions Vs. Previous Experimental Measurements [3], for Tempt. Sensor (T-31)

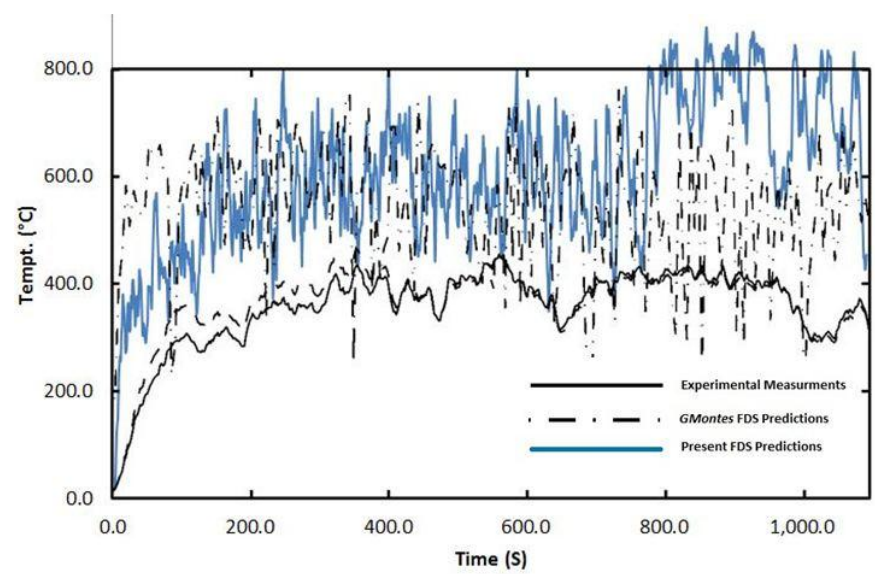

Fig. 8 Present CFD Predictions Vs. Previous Experimental Measurements [3], for Tempt. Sensor (T-24)

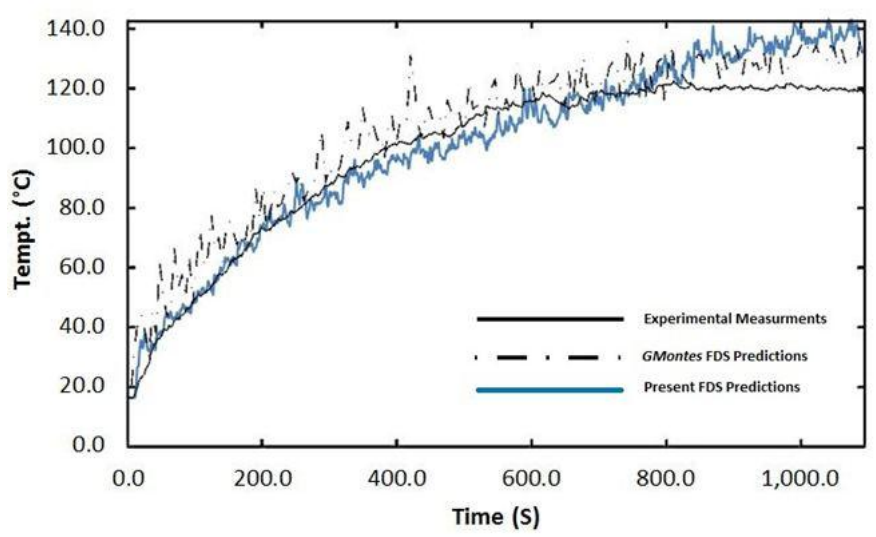

Fig. 9 Present CFD Predictions Vs. Previous Experimental Measurements [3], for Tempt. Sensor (T-60)

\section{RESULTS AND DISCUSSION}

The results of the CFD simulations reveal that the relative error between the present simulations and the experimental measurements [3] are very low for temperature sensors with heights more than $10 \mathrm{~m}$, below $5 \%$ relative error, and low for temperature sensors with height less than $10 \mathrm{~m}$, below $15 \%$ relative error, except for the temperature sensors located above the fire source (flame), the relative errors for these temperature sensors are $60-80 \%$ below $10 \mathrm{~m}$ height and decreases to $30 \%$ at $12 \mathrm{~m}$ height. At the center top of the atrium, on the exhaust outlets locations, the present simulations relative error was very low compared to the experimental measurements $(2.3 \%)$.

The reason behind the high relative error in the temperature sensors above the fire source (T-24, T-31, \& T-28) was thoroughly. After analyzing, it was found that the errors of these sensors were because the HRR provided in the previous study is for the first 250 seconds only, as in Fig. 1. The FDS continued using the last value as constant value till the end of the simulation time, 1094 s, as in Fig. 10 below. This resulted in a flashover.

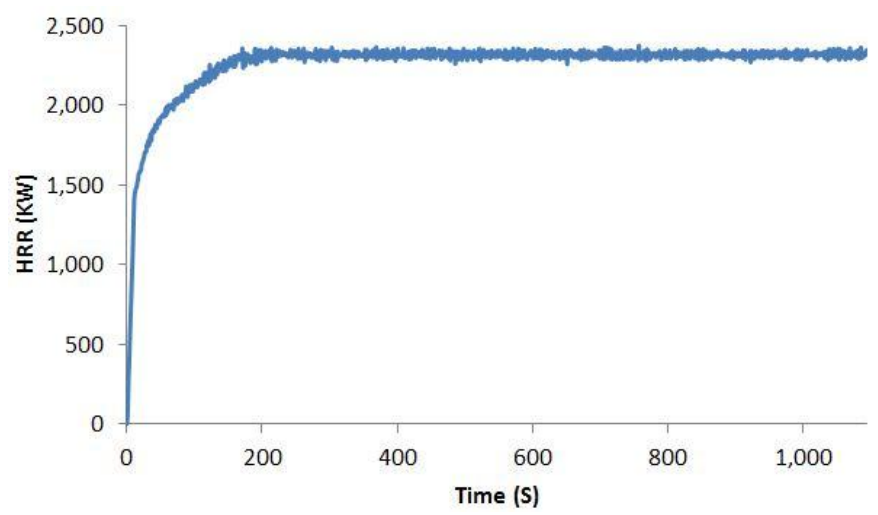

Fig. 10 Heat Release Rate (HRR) variation with time for present simulation 
Flashover is a rapid change from a growth stage fire to a fully developed fire. Flashover generally happens when the smoke layer is in the range of $\left(500{ }^{\circ} \mathrm{C}\right.$ to $\left.700{ }^{\circ} \mathrm{C}\right)$ [9]. Another researches suggested that the criteria for a flashover of a smoke layer temperature of around $600^{\circ} \mathrm{C}$ or a radiant heat flux of $20 \mathrm{KW} / \mathrm{m} 2$ at the floor of the fire room [7], which already occurs in the present case starting from T-24 in Fig. 8 after around 750 seconds with average temperature of $600^{\circ} \mathrm{C}$ and continuing with T-31 and T-28 in Fig. 7 \& Fig. 6 respectively.

Moreover, the rest of the results show very good predictions when compared to the experimental measurements, which agrees with previous simulation [3]. The average relative errors for the temperature sensors which are not directly $10 \mathrm{~m}$ above the flame (fire) did not exceed $15 \%$ in the present simulation.

\section{CONCLUSION}

This concludes that using FDS in designing a smoke management system in atrium is a very efficient way as it is cheaper than the other methods like scale tests, and the simulation predictions are very close to the reality if used properly.

\section{REFERENCES}

[1] ASHRAE Handbook of Smoke Control Engineering, Chapter 15, Basics of Atrium Smoke Control, P. 315.2012

[2] Gutie'rrez-Montes C, Sanmiguel-Rojas E, Kaiser AS, Viedma A. Numerical model and validation experiments of atrium enclosure fire in a new fire test facility. Building and Environment 2008;43(11):1912-28. https://doi.org/10.1016/j.buildenv.2007.11.010

[3] Ca'ndido Gutie' rrez-Montes a, *, Enrique Sanmiguel-Rojas a, Antonio Viedma b, Guillermo Rein. Experimental data and numerical modelling of 1.3 and $2.3 \mathrm{MW}$ fires in a $20 \mathrm{~m}$ cubic atrium, 2008

[4] McGrattan K. In: Fire dynamics simulator (version 4) technical reference guide. National Institute of Standards and Technology, Special Publication 1018; 2004.

[5] Kevin McGrattan, Simo Hostikka,, Randall McDermott, Jason Floyd, Craig Weinschenk, Kristopher Overholt. NIST Special Publication 1018-3. Sixth Edition. Fire Dynamics Simulator, Technical Reference Guide, Volume 3: Validation.2016

[6] Dreisbach J, McGrattan K. Verification and validation of selected fire models for nuclear power plant applications. In: Fire dynamics simulator (FDS), NUREG-1824 final report, vol. 7. U.S. Nuclear Regulatory Commission, Office of Nuclear Regulatory Research; May 2007.

[7] Richard D. Peacock, Paul A. Reneke, Richard W. Bukowski, Vytenis Babrauskas. Defining flashover for fire hazard calculations. Fire Safety Journal 32(4):331-345 - June 1999

[8] Bounagui, A.; Bénichou, N.; Mccartney, C. J.; Kashef, A. Optimizing the grid size used in CFD simulation to evaluate fire safety in houses. 3rd NRC Symposium on Computational Fluid Dynamics, High Performance Computing and Virtual Reality: 04 December 2003, Ottawa, Ontario

[9] ASHRAE Handbook of Smoke Control Engineering, Chapter 5, Basics of Atrium Smoke Control, P. 151,2012 